\title{
Aridity Indices to Assess Desertification Susceptibility: A Methodological Approach Using Gridded Climate Data
}

\section{Janaína Cassiano dos Santos}

Federal Fluminense University: Universidade Federal Fluminense

\section{Gustavo Bastos Lyra ( $\nabla$ gblyra@ufrrj.br)}

Federal Rural University of Rio de Janeiro: Universidade Federal Rural do Rio de Janeiro https://orcid.org/0000-0002-9882-7000

\section{Marcel Carvalho de Abreu}

Federal Rural University of Rio de Janeiro: Universidade Federal Rural do Rio de Janeiro

\section{José Francisco de Oliveira-Júnior}

Federal University of Alagoas: Universidade Federal de Alagoas

\section{Leonardo Bohn}

Federal University of Rio Grande do Sul: Universidade Federal do Rio Grande do Sul

\section{Gisleine Cunha-Zeri}

Center for Earth System Science, National Institute for Space Research

\section{Marcelo Zeri}

National Center for Monitoring and Early Warming of Natural Disaster

\section{Research Article}

Keywords: Desertification, Gridded datasets, Geoprocessing, Aridity Index, Climate

Posted Date: April 21st, 2021

DOI: https://doi.org/10.21203/rs.3.rs-432333/v1

License: (a) (1) This work is licensed under a Creative Commons Attribution 4.0 International License. Read Full License 


\section{Aridity indices to assess desertification susceptibility: a} methodological approach using gridded climate data

Janaína Cassiano dos Santosa, Gustavo Bastos Lyrab, ${ }^{\text {, }}$, Marcel Carvalho de Abreub, José Francisco de Oliveira-Júniorc, Leonardo Bohnd, Gisleine Cunha-Zerie, Marcelo Zerif $^{f}$

\section{Affiliations}

a Programa de Pós-Graduação em Engenharia de Biossistemas, Departamento de Engenharia Agrícola e do Meio Ambiente, Escola de Engenharia, Universidade Federal Fluminense, 24.210-240, Niterói, Rio de Janeiro, Brasil.

b Departamento de Ciências Ambientais, Instituto de Florestas, Universidade Federal Rural do Rio de Janeiro, 23.890-000, Seropédica, Rio de Janeiro, Brasil.

c Instituto de Ciências Atmosféricas, Universidade Federal de Alagoas, Campus A.C. Simões, BR 104-Norte, Km 97, Tabuleiro dos Martins, 57.072-970, Maceió, Alagoas, Brasil.

d Programa de Pós-Graduação em Desenvolvimento Rural (PGDR), Centro Interdisciplinar Sociedade, Ambiente e Desenvolvimento (CISADE), Faculdade de Ciências Econômicas (FCE), Universidade Federal do Rio Grande do Sul (UFRGS), Porto Alegre, Rio Grande do Sul, Brazil.

e Center for Earth System Science (CCST), National Institute for Space Research (INPE), 12227-010, São José dos Campos, SP, Brazil.

f National Center for Monitoring and Early Warning of Natural Disasters (CEMADEN), 12247-016, São José dos Campos, SP, Brazil.

\section{*Corresponding author:}

Gustavo B. Lyra

orcid.org/0000-0002-9882-7000

Departamento de Ciências Ambientais, Instituto de Florestas, UFRRJ

Cidade Universitária, Rod BR 465, Km 7

CEP 23890-000 - Seropédica, Rio de Janeiro, Brazil

e-mail: gblyra@ufrrj.br 
Desertification is a land degradation phenomenon with dire and irreversible consequences, affecting different regions of the world. Assessment of spatial susceptibility to desertification requires long-term series of precipitation (P) and evapotranspiration (PET). An approach to desertification analysis is the use of spatially gridded time series of air temperature and precipitation, derived from spatial interpolation of in situ measurements and available globally. The aim of this article was to estimate the susceptibility to desertification over Southeast Brazil using monthly gridded data from the Global Precipitation Climatology Centre (GPCC), and from the Global Historical Climatology Network (GHCN). Two indices were used to estimate desertification susceptibility: the aridity index $I_{a}(\mathrm{P} / \mathrm{PET})$ and D (PET/P). Validation of these datasets was performed using in situ observations (1961-2010) from the National Institute of Meteorology (INMET) (68 weather stations). Determination coefficient $\left(r^{2}\right)$ and the Willmott's coefficient of agreement $(d)$ between gridded and observed data revealed satisfactory accuracy and precision for grids of precipitation $\left(r^{2}>0.93, d>0.90\right)$, air temperature $\left(r^{2}>0.94, d>0.53\right)$ and PET $\left(r^{2}>0.93, d>0.63\right)$. Areas susceptible to desertification were identified by the index $I_{a}$ over the Northern regions of Minas Gerais and Rio de Janeiro states. No areas susceptible to desertification were identified using the index $D$. However, both indices indicated large areas of dry sub-humid climate, which can be strongly affected by drought conditions. Overall, climate gridded variables presented good precision and accuracy when used to identify areas susceptible to desertification. 
Funding:

57 Fundação Carlos Chagas Filho de Amparo à Pesquisa do Estado do Rio de Janeiro (No

58 141.663) - D.Sc. Gustavo Bastos Lyra

Conselho Nacional de Desenvolvimento Científico e Tecnológico (No 483643/2011-4 and No 435238/2018-3) - D.Sc. Gustavo Bastos Lyra

61 Fundação Carlos Chagas Filho de Amparo à Pesquisa do Estado do Rio de Janeiro (No E-

62 26/201.501/2014) - D.Sc. Gustavo Bastos Lyra

Conselho Nacional de Desenvolvimento Científico e Tecnológico (No 309681/2019-7) - Dr.

64 José Francisco de Oliveira-Júnior

65 Coordenação de Aperfeiçoamento de Pessoal de Nível Superior (No 88887.308408/2018-

66 00) M.Sc. Gisleine Cunha-Zeri

67 Coordenação de Aperfeiçoamento de Pessoal de Nível Superior (No 0001) - Ms. Janaína

68 Cassiano dos Santos

69

Conflicts of interest/Competing interests: Not applicable

Availability of data and material: The observed data used in the present study are made available by the National Meteorological Institute (INMET) of Brazil and the gridded data by the Climate Data Center - NOAA.

National Meteorological Institute

\section{https://portal.inmet.gov.br/servicos/bdmep-dados-hist\%C3\%B3ricos}

Global Historical Climatology Network (GHCN)

https://www.ncdc.noaa.gov/data-access/land-based-station-data/land-baseddatasets/global-historical-climatology-network-ghcn

Global Precipitation Climatology Centre (GPCC)

https://data.noaa.gov/dataset/dataset/global-precipitation-climatology-centre-gpcc

Code availability: Not applicable

Additional declarations for articles in life science journals that report the results of studies involving humans and/or animals: Not applicable 
90 Ethics approval: Not applicable

91

92 Consent to participate: Not applicable

93

94 Consent for publication: Not applicable

95 


\section{Introduction}

Desertification is regarded as the most acute land degradation process. The phenomenon is defined as a reduction of biological or economical productivity, reduction of complexity in the natural landscape, soil degradation (erosion) and loss of vegetation cover (Sivakumar 2007). Desertification is especially critical over regions with dry climate, where water resources recharge during the raining season is lower than the water lost due to evapotranspiration. The phenomenon is considered irreversible when present in large scale, affecting directly and indirectly natural resources and livelihoods of local populations (Hare 1983; Sivakumar 2007; Almeida et al. 2014).

Desertification is a complex and dynamical process affecting arid, semi-arid and subhumid regions, and influenced by several factors such as climate variability, relief, soil, biophysical phenomena, and anthropic activities (Vieira et al. 2015, 2020; Tomasella et al. 2018). The process is triggered by an accelerated degradation of natural vegetation and soil, beyond the natural regenerative capacity of the landscape. Land degradation can be associated with agriculture over inappropriate areas, deforestation of native vegetation, forest fires, poor use of irrigation, mining activities, and climate. When considering the climate, the main factors affecting desertification are high temperature, low precipitation, which leads to poor formation of organic matter and fast oxygenation in soils, increasing erosion damages (Sivakumar 2007).

The consequences of desertification extrapolate geographical limits by impacting the food production and migrations to less vulnerable areas. Currently, it is estimated that one billion people in 100 countries are affected by desertification, with 250 million in developing nations (Reynolds et al. 2007). In Brazil, most of the studies on desertification focus on the Northeast region due to its semi-arid climate and high number of municipalities with high vulnerability to drought (Marengo et al. 2017; Ferreira et al. 2017; Tomasella et al. 2018; Alves et al. 2020; Vieira et al. 2020). However, other regions of the country have similar climate and issues of environmental degradation, increasing the risk of desertification. In addition, climate change projections on spatial and temporal patterns of precipitation and air 
temperature increase the threat of desertification over areas not currently under risk (Sivakumar et al. 2007).

The United Nations Environment Program (UNEP) adopted in 1991 the aridity index $\left(I_{a}\right)$ as a measure of susceptibility to desertification (Mirzabaev et al. 2019). This index is calculated by dividing annual precipitation (P) by total evapotranspiration (PET) in the same period. Higher probability of desertification is expected when this ratio is below 0.65 . A second formulation for the aridity index $(D)$ considers the ETP divided by R. In this case, areas susceptible to desertification have $D$ in the range of 2 to 7 , related to the dry conditions of wet climate zones to the sub-humid climate of deserts (Hare 1983; Bohn 2014).

Patterns of precipitation over Southeast Brazil (SEB) are associated with the passage of frontal systems and, during the summer, the South Atlantic Convergence Zone (SACZ), a band of clouds oriented NW-SE (Satyamurty et al. 1998; Brito et al. 2017; Andrade and Cavalcanti 2018; Lyra et al. 2018). Frontal systems (FS) are more common in spring and winter, but total precipitation is highest for events during the months of spring and summer (Andrade and Cavalcanti 2018). The SACZ accounts for $25 \%$ of precipitation between October and April, on average, with peaks of $41 \%$ in January and 56\% in March (Nielsen et al. 2019). SEB has fourteen climate subtypes and topographical features that enhance precipitation variability such as low and high altitude regions, and the proximity to the coast (Sant'Anna Neto 2005; Cataldi et al. 2010; Nobre et al. 2013 ;Vieira et al. 2015; Rao et al. 2016).

Studies of desertification require long-term time series of precipitation and air temperature. Over SEB, data coverage is irregular in space and time, with long gaps in data records and regions with poor spatial coverage (Santos et al. 2018; Oliveira Júnior et al. 2012; Lyra et al. 2018). An alternative is the use of global gridded climate data, which are generated from the spatial interpolation of in situ observations (Peterson and Vose 1997; Willmott et al. 2001; Jones and Moberg 2003; Tostes et al. 2017) simulated by numerical climate models (Kalnay et al. 1996; Kanamitsu et al. 2002) or obtained from remote sensing (e.g. Tropical Precipitation Measuring Mission, TRMM) (Kawanishi et al. 1993, 2000). Other useful databases are the Global Historical Climatology Network (GHCN) - (Jones and Moberg 2003) and the Global 
Precipitation Climatology Center (GPCC) - (Schneider et al. 2014), provided by the National Oceanic and Atmospheric Administration (NOAA) - (NOAA 2020). These datasets have good spatial resolution $\left(0.5 \times 0.5^{\circ}\right)$ over a regular grid, and time series longer than 50 years with no gaps, originated from more than 20 sources around the world.

The objective of this study was to investigate the susceptibility to desertification over SEB using gridded climate data. The study is timely considering the lack of studies of desertification over an area with vulnerabilities in the social (de Loyola Hummell et al. 2016) and environmental domains (Almeida et al. 2014), where an estimated population of 80,364,410 inhabits and, recently, there was a water crisis that affected water supply, industry and energy generation. A secondary objective of this study was to assesses the performance of global gridded datasets when used to estimate PET and the aridity indices.

\section{Material and Methods}

The Brazilian Southeast is located within coordinates $15^{\circ}$ and $25^{\circ} \mathrm{S}$, and longitudes $39^{\circ}$ and $53^{\circ} \mathrm{W}$, with longitudinal range extending from the coast to the Atlantic Ocean up to $1000 \mathrm{~km}$ within the continent. The region includes four states: Espírito Santo, Rio de Janeiro, Minas Gerais and São Paulo (Figure 1). SEB is characterized by a complex topography, with extensive valleys, such as Paraíba do Sul, Jequitinhonha and São Francisco do Sul, and highlands such as Serra do Mar, Mantiqueira, among others (Sant'Anna Neto 2005). Altitude in the region varies between mean sea level up to 2891 m, at Pico da Bandeira (Nimer 1972).

\section{Figure 1}

\subsection{Time series of meteorological data}

The gridded data of air temperature and precipitation were obtained from two sources: the GHCN and GPCC, both described in the Introduction. Records are available in NetCDF formats with spatial resolution of $0.5 \times 0.5^{\circ}$. Evaluation of this dataset was performed using records from conventional weather stations across 
SEB. Time series of air temperature $\left(\mathrm{T},{ }^{\circ} \mathrm{C}\right)$ and precipitation $(\mathrm{P}, \mathrm{mm})$ were obtained for the period of 1961 to 2010, from a set of 68 stations located within SEB (Table 1). Records are maintained by the National Institute of Meteorology (INMET). Quality control was carried out using homogeneity tests, physical consistency and analysis of gaps. Details of the quality control can be found previously published works (Brito et al. 2017; Lyra et al. 2018).

\section{Table 1}

\subsection{Desertification indices}

Monthly data of precipitation and air temperature were used as inputs in the calculation of the Climatological Water Balance (CWB) - (Thornthwaite and Mather 1955), resulting in the annual evapotranspiration and precipitation. Those estimates are essential in the calculation of aridity indices. Dynamical tables were created in Microsoft Excel to calculate monthly means for the period 1961-2010 for each station selected. Next, a new Excel file was created with annual values of PET and precipitation where the indices were calculated.

The method of Thornthwaite is based on the following equations:

$$
\mathrm{PET}=\mathrm{ET}_{\mathrm{pp}} \frac{N}{12} \frac{\mathrm{ND}}{30}
$$

where PET (mm) is the potential evapotranspiration, $N$ (hours) is the maximum number of daytime hours, $P E T_{p p}$ is the potential evapotranspiration for a 30 days month with 12 hours of daylight, and $N D$ is the number of days of the current month. $P E T_{p p}$ is calculated as:

$$
\operatorname{PET}_{\mathrm{pp}}=16\left(10 \frac{\mathrm{T}_{\mathrm{m}, \mathrm{i}}}{\mathrm{I}}\right)^{\mathrm{a}} \mathrm{T}_{\mathrm{m}, \mathrm{i}}>0^{\circ} \mathrm{C}
$$

where the subscript $i$ represents the $i^{\text {th }}$ month. The parameter $I$ and $a$ are the regional heat indices obtained from monthly means of air temperature.

Having calculated PET and P for each grid point, the aridity index $I_{a}$ developed by (Thornthwaite 1948) and adjusted by (Penman 1953) was calculated as: 


$$
I_{a}=\frac{P}{\mathrm{PET}}
$$

The $I_{a}$ index can be interpreted by Table 2 .

\section{Table 2}

214 The aridity index $D$ (Hare 1983) was determined following this expression:

$$
\begin{aligned}
& D=\frac{1}{(0,01 I m+1)} \\
& I m=100\left[\left(\frac{P}{P E T}\right)-1\right]
\end{aligned}
$$

215 replacing 5 in 4 and organizing your terms:

$$
D=\left(\frac{P E T}{P}\right)
$$

\subsection{Statistical Analyses}

218 The gridded climate data were evaluated against observations from in-situ stations.

219 Records of total monthly precipitation and mean air temperature were extracted from grid points closer to the station's coordinates. Linear regression was used to compare both datasets. The same approach was applied to time series of PET and the aridity indices. This evaluation enables the identification of metrics of precision and accuracy between gridded and observed data (Oliveira Júnior et al. 2012; Brito et al. 2017; Tostes et al. 2017; Santos et al. 2018; Lyra et al. 2018).

225 The coefficient of determination $\left(r^{2}\right)$ (Equation 5) was used to evaluate the precision 226 of gridded data against observed records. The value of $r^{2}$ ranges from 0 to 1, where 227 proximity to 1 indicates higher precision and less dispersion of gridded data in relation to observations, i.e., linearity between the two datasets (Wilks 1995). 


$$
r^{2}=\left[\frac{\sum_{i=1}^{n}\left(O_{i}-\bar{O}\right) \cdot\left(E_{i}-\bar{E}\right)}{\sqrt{\sum_{i=1}^{n}\left(O_{i}-\bar{O}\right)^{2} \cdot \sum_{i=1}^{n}\left(E_{i}-\bar{E}\right)^{2}}}\right]^{2}
$$

229 In Equation $5 \overline{\mathrm{O}}$ represents the mean of observations, $\overline{\mathrm{E}}$ is the mean of estimated 230 values, and $\mathrm{n}$ is the number of records.

231 In addition, the index of agreement (d) was calculated as (Willmott 1981):

$$
\mathrm{d}=1-\left[\frac{\sum_{i=1}^{n}\left(O_{i}-\mathrm{E}_{i}\right)^{2}}{\sum_{i=1}^{n}\left(\left|E_{i}-\bar{O}\right|+\left|O_{i}-\bar{O}\right|\right)^{2}}\right]
$$

232 In Equation 6, $O_{i}$ and $E_{i}$ represent the $i^{\text {th }}$ observation and estimated value, respectively. The index of agreement measures the accuracy of gridded data in relation to observed data. The index has a range of 0 to 1 , with 1 indicating higher 235 accuracy.

236 The error is the analyses was evaluated using three metrics: RMSE - Root Mean 237 Square Error, MAE - Mean Absolute Error, and MBE - Mean Bias Error, all expressed 238 in Eq. 9, 10 and 11:

$$
\begin{aligned}
& \text { RMSE }=\sqrt{\sum_{i=1}^{n} \frac{\left(E_{i}-O_{i}\right)^{2}}{n}} \\
& \text { MAE }=\frac{1}{n} \sum_{i=1}^{n}\left|O_{i}-E_{i}\right| \\
& \operatorname{MBE}=\frac{1}{n} \sum_{i=1}^{n}\left(O_{i}-E_{i}\right)
\end{aligned}
$$

239 The RMSE is a measure of error between sampled and estimated values. The MAE 240 measures the magnitude of errors not considering bias in observations or 241 estimations. Finally, the MBE measures the error between observations and 242 estimated values, having a positive sign if the latter are underestimated in relation 
to the former. The opposite, negative values of $\mathrm{MBE}$, indicate that estimations extrapolate the observed values (Wilks 1995).

The RMSE can be expressed as the sum of its systematic error (RMSEs) and unsystematic error (RMSEu) (Willmott 1981):

$$
\begin{aligned}
& \operatorname{RSME}_{s}=\sqrt{\left[\frac{\sum_{\mathrm{i}=1}^{\mathrm{N}}\left(\widehat{E}_{1}-O_{\mathrm{i}}\right)^{2}}{\mathrm{~N}}\right]} \\
& \operatorname{RSME}_{u}=\sqrt{\left[\frac{\sum_{\mathrm{i}=1}^{\mathrm{N}}\left(\widehat{E}_{1}-E_{\mathrm{i}}\right)^{2}}{\mathrm{~N}}\right]}
\end{aligned}
$$

247 where, $\widehat{E_{1}}=\beta_{o}+\beta_{1} O_{i}$.

\subsection{Multivariate Analysis}

250

251

252

253

254

Multivariate analysis was used to group the data of air temperature, precipitation and PET into spatial homogeneous patterns. Ward's hierarchical clustering method was used with Euclidean squared distance $\left(d_{e}\right)$ as a measure of dissimilarity (Ward 1963; Murtagh 1985). The distance de was calculates as:

$$
d_{e}=\sqrt{\sum_{i=1}^{n}\left(P_{\mathrm{p}, \mathrm{i}}-P_{\mathrm{k}, \mathrm{i}}\right)^{2}}
$$

where $P_{p, i}$ and $P_{k, i}$ are variables representing elements $\mathrm{p}$ and $\mathrm{k}$, respectively. Calculations were performed using the library hclust from the software R (version 3.5.1) - (R Development Core Team 2011).

\section{Results and Discussion}

\subsection{Evaluation of gridded climate data}

The coefficient $r^{2}$ between observed and gridded precipitation data varied between 0.93 (stations São Mateus and Formoso) to 0.99 (Patos de Minas, Florestal, Conceição 
do Mato Dentro, Divinópolis and Arinos) (supplementary material S1). The range of $r^{2}$ indicates a low dispersion of the gridded data in relation to the observations. Regarding index of agreement d, only Rio de Janeiro city (ID 56) presented a value below $0.9\left(d=0.79\right.$, supplementary material S2). The values of $r^{2}$ and $d$ obtained in this study are higher than values reported in other studies for this region (Santos et al. 2018; Lyra et al. 2018), indicating a good precision and accuracy of the gridded data when representing the seasonal trends of precipitation over SEB.

Precipitation RMSE varied between 6.1 (station Florestal, ID 33) to $48.6 \mathrm{~mm}$ (Rio de Janeiro, supplementary material S3). The highest values of RMSE were observed in the border regions of SEB, especially the coastal regions and Minas Gerais Northeast; the lowest values of RMSE were observed at the center and Southwest of Minas Gerais, Rio de Janeiro state Northwest, and North of São Paulo state. The relation between RMSE and average precipitation was approximately $14 \%$.

The high values of RMSE over the coastal areas are likely associated with the climatological and physical systems affecting the region in association with the complex topography (Brito et al. 2017; Lyra et al. 2018). The distribution of ocean currents might be an important influence given that the SEB region is close to the confluence of two currents: the Brazilian and the Malvinas currents (Cataldi et al. 2010). Finally, the absence of stations over the ocean might influence the RMSE due to interpolation and border effects.

The coefficient $r^{2}$ between gridded (GHCN) and observed air temperature data indicated good precision, with lowest value observed for Espinosa station (ID 7, $r^{2}=$ 0.94, supplementary material S4). Data over Northern Minas Gerais state presented the lowest $r^{2}$, similar to the pattern observed for the gridded data of precipitation; lowest values of the index of agreement $d$ were also observed for this region (supplementary material S5). The lowest accuracy was observed for the Minas Gerais stations of Arinos ( $\mathrm{d}=0.53$ ), Campos do Jordão (ID 62, $\mathrm{d}=0.56$ ) and Frutal (ID 30, $d=0.6$ ). It should be noted that all those stations are located over $500 \mathrm{~m}$ a.s.l. The results here indicate that gridded data of air temperature have high precision and low accuracy, particularly over high altitude. The values of RMSE for air temperature were in the range of 0.16 (São Mateus) and $5.04^{\circ} \mathrm{C}$ (Campos do Jordão, 
supplementary material S6). The lowest values of RMSE were observed over central SEB, in addition to Northern São Paulo and Rio de Janeiro states, and over Northeast Minas Gerais.

The discrepancy between accuracy and precision of gridded air temperature might be attributed to the complex topography and to the distance of grid points to the nearest meteorological station (Santos et al. 2018). Nevertheless, the errors are acceptable to be used in climate studies, given the poor distribution and availability of historical data over Brazil (Donat et al. 2014; Tostes et al. 2017; Macharia et al. 2020).

The analysis of $r^{2}$ between gridded and observed PET data indicated a good precision. PET data presented high values of $r^{2}$, with the lowest $r^{2}$ over Florestal station (0.93), followed by Espinosa (0.95), while 51 stations presented values higher than 0.99 (supplementary material S7). The coefficient of agreement $d$ indicated high variability of accuracy, especially over Northern Minas Gerais, where the lowest values were observed ( 0.63 for Arinos and 0.72 for Frutal, supplementary material S8). Similar to air temperature, gridded ETP data was more precise than accurate. This was expected since ETP is derived from air temperature via the method of Thornthwaite. The values of RMSE obtained ranged from 1.5 (Juiz de Fora, ID 49) and $42.4 \mathrm{~mm}$ (Arinos, ID 1), where the relative departure from the mean was of $1 \%$, and $11.6 \mathrm{~mm}$ in absolute terms (supplementary material S9). In spite of the RMSE values, the gridded PET data were found to be suitable for this study, especially when compared to errors estimates found in other studies (Monteiro et al. 2016; Mourtzinis et al. 2017; Santos et al. 2018).

Results from the statistical analyses indicated that annual means presented higher accuracy $(d)$ than precision $\left(r^{2}\right.$, Figure 2, Table 3). High dispersion was observed in regression results $\left(r^{2}=0.51\right)$, but values were distributed near the 1:1 line, resulting in satisfactory values of $\mathrm{d}$. Values of $r^{2}$ for annual air temperature, precipitation and PET were lower than monthly estimates. Overall monthly data presented higher precision $\left(r^{2}\right)$ and accuracy $(d)$ than annual data, which could be attributed to several factors such as: fewer data, low homogeneity in original data, and nonstationarity in historical records. Here stationarity is assumed as low variability of 
statistical moments in a time series (Wilks 1995). These results indicate that time series are more precise and accurate when used to represent the seasonal patterns of climate, in comparison to the spatial characterization (Lyra et al. 2018).

\section{Figure 2}

\section{Table 3}

Precipitation data from five stations (Avelar - ID 51, Rio de Janeiro, Cordeiro - ID 54, Resende - ID 55, and Santana - ID 66) was characterized by high systematic error (> $90 \%$ ) and influenced the statistical analysis. Those stations are located over high altitude and complex topography and were not excluded from the study. However, testing of calculations without those stations resulted in $\mathrm{r}^{2}$ of 0.91 and $d$ of 0.91 , not significantly different. Regarding air temperature, the only station with high residuals was Campos do Jordão, located over high altitude (1686 m); when removed from the analysis, annual values of $r^{2}$ and $d$ were of 0.54 and 0.81 , respectively, while the systematic error decreased by $48.8 \%$. Precipitation presents high spatial variability due to its strong dependence on local topographic effects and meteorological systems; this dependence is less strong in other variables, such as air temperature (Vicente-Serrano et al. 2003; Silva et al. 2011). Thus, the high residuals found for those five stations are likely related to the interaction of meteorological systems and the complex topography, which greatly influence precipitation variability over the area (Brito et al. 2017; Sobral et al. 2018; Lyra et al. 2018; Gois et al. 2020).

The relative RMSE values were lower than $10 \%$ for annual precipitation, and lower than 13.8\% for annual PET. According to values of RMSEu and RMSEs (Table 3), most of the errors for air temperature and PET were systematic. The high value of systematic error for PET (65.6\%) is most likely caused by its calculation procedure using Thornthwaite's method. This method is dependent on air temperature, thus errors in the gridded air temperature (RMSE $=1,57^{\circ} \mathrm{C}$ ) data are propagated to PET.

The value of MBE was negative for precipitation $(-64.5 \mathrm{~mm})$, indicating that the gridded data were, on average, overestimated in relation to observations. Underestimation was observed for air temperature $\left(0.7^{\circ} \mathrm{C}\right)$ and PET $(84.3 \mathrm{~mm})$. Values of MAE were lower than RMSE for air temperature (Table 3). These two 
error estimates do not indicate the sign of departures (overestimation or underestimation); instead, the lower their magnitude the better are the results.

Accuracy and precision for the aridity indices $\left(I_{a}\right.$ and $\left.D\right)$ were $\operatorname{good}\left(d>0.88, r^{2}>\right.$ 0.7), indicating the suitability of gridded data to detect the spatial patterns of both indices. The index $I_{a}$ presented higher dispersion between observed and gridded data in relation to index $D$; both indices presented similar accuracy and relative RMSE.

The index $D$ underestimated observed values higher than 1 , which could lead to classification errors of areas susceptible to desertification or sub-humid. This error was caused by the underestimation of air temperature by the gridded data, leading to underestimation of PET and $D$, since $\mathrm{D}=\mathrm{PET} / \mathrm{P}$. The opposite was observed for index $I_{a}=\mathrm{P} / \mathrm{PET}$, with overestimation for values higher than 2 , due to errors in precipitation. However, in relative terms, the overestimation of $I_{a}$ was lower than that of $D$. Higher discrepancy was observed for index $\mathrm{I}_{\mathrm{a}}$ over the station of Campos do Jordão. When removed from the analysis, values of $\mathrm{r}^{2}$ increased from 0.74 to 0.76 . Due to the insignificant change, this station was not removed from the analysis.

\subsection{Spatial and seasonal climate patterns}

\subsubsection{Seasonal patterns}

Five groups of homogeneous precipitation, air temperature and PET were identified by clustering analysis (Figure 3). Group 1 (G1) consisted of six stations over the central and Northern parts of the SEB (states of Rio de Janeiro and Espírito Santo) and 1 station in Presidente Prudente (ID 63), West of São Paulo state (Figure 4). All stations of G1 are located within the biome Mata Atlântica (Atlantic Forest), which is characterized by wet tropical climate with dry winters, according to the KöppenGeiger classification (Alvares et al. 2013). Stations in G1 presented average annual air temperature of $24.8^{\circ} \mathrm{C}( \pm 0.6)$, annual precipitation of $1108.4 \mathrm{~mm}( \pm 148.4)$ and annual PET of $1388.7 \mathrm{~mm}( \pm 91.3)$. 
Group 2 (G2) consisted of 14 stations located over Eastern and Southeastern São Paulo state, and over Southern and Southeastern Minas Gerais. This region is characterized by Atlantic Forest vegetation, temperate oceanic climate, and drywinter subtropical highland climate (Alvares et al. 2013). Topographic features of this region include mountain ranges Serra do Mar (coastal highlands), Serra da Mantiqueira, and Serra do Caparão. Among all groups, stations in G2 presented the lowest average annual air temperature $\left(19.9 \pm 1.67^{\circ} \mathrm{C}\right)$ and PET $(934.7 \pm 82.7 \mathrm{~mm})$, and the highest annual totals of precipitation (1480.6 $\pm 130.3 \mathrm{~mm})$. Altitude of stations ranged from $645 \mathrm{~m}$ a. s. l. (Sorocaba) to $1642 \mathrm{~m}$ a. s. l. (Campos dos Jordão).

Group 3 (G3) stations are located over Northern and Northeastern Minas Gerais. Predominant biomes are Caatinga and Cerrado, and climate ranges from dry subhumid to semi-arid, with dry season in summer (Alvares et al. 2013). Those regions presented, among all groups, the lowest annual totals of precipitation (813.7 \pm 62.7 $\mathrm{mm})$ and the highest mean annual air temperature $\left(25.0 \pm 0.5^{\circ} \mathrm{C}\right)$ and PET $(1404.5 \pm$ $71.3 \mathrm{~mm})$.

Stations of Group 4 (G4) were concentrated over Western and Northwestern Minas Gerais and Northern São Paulo state. The 16 stations of G4 presented climatological characteristics of savannah (Köppen-Geiger), with dry season during winter. Mean annual precipitation was of $1196.9 \mathrm{~mm}( \pm 166.9)$, mean annual air temperature was $24^{\circ} \mathrm{C}( \pm 0.7)$ and average PET was $1284.5 \mathrm{~mm}( \pm 103.3)$.

Group 5 (G5) was the largest with 24 stations located over the highlands of Rio de Janeiro and São Paulo states, and central South of Minas Gerais (below $18^{\circ} \mathrm{S}$, between 41.5 and $\left.49.5^{\circ} \mathrm{W}\right)$. Average annual air temperature was of $21.8^{\circ} \mathrm{C}( \pm 0.6)$, mean annual precipitation was $1390.9 \mathrm{~mm}$ ( \pm 171.3$)$, and average PET was 1057.3 $\mathrm{mm}( \pm 52.3)$. This region is characterized by the intersection of biomes Mata Atlântica and Cerrado, and its climate is classified as wet subtropical of altitude with warm summer (Alvares et al. 2013). Weather in this region is highly influenced by the monsoons and the SACZ (Ambrizzi and Ferraz 2015; Coelho et al. 2016; Kelly and Mapes 2016; Rodrigues et al. 2019; Nielsen et al. 2019). 
414 Overall, the lowest annual precipitation totals and highest air temperature and PET 415 were found for stations of groups G1 and G3 (first and second in rank). Conversely, 416 the two groups with highest annual precipitation and lowest air temperature and 417 PET were groups G2 followed by G5. Stations of group G4 presented characteristics 418 of precipitation, air temperature and PET between these two patterns. Patterns observed for groups G1 and G3 are related to the heterogeneous nature of precipitation over the coastal SEB (Sant'Anna Neto 2005). Groups G5 and G2 are influenced by the interaction of southern and southeastern moisture enriched winds from the Atlantic Ocean with the topography of Serra do Mar mountain range, in addition to low level convergence of hot and humid air, increasing precipitation over the ocean facing side of the mountain range, while decreasing precipitation towards the interior of the continent (Sant'Anna Neto 2005; Seluchi et al. 2011; Brito et al. 2017; Gois et al. 2020).

The monthly variability was evaluated using boxplots for each group and variable (Figure 5). Precipitation presented a well-defined seasonal pattern, with reductions from summer (DJF) to winter (JJA), as previously reported for this region (Rao et al. 2016). Precipitation variability is related to the seasonal patterns of frontal systems, more frequent during summer and spring (Andrade and Cavalcanti 2018), followed by the occurrence of mesoscale convective systems, during the warm period of October to May (Satyamurty et al. 1998; Brasiliense et al. 2018;). The exception was February for groups G1 and G3, with lower totals in comparison with March. This result is associated with the occurrence of dry spells in the region (Brito et al. 2017; Cunningham 2020). Groups G1 and G3 presented the highest totals (> $145 \mathrm{~mm}$ ) during the month range of NDJ; this range was NDJFM for groups G2, G4 and G5. The lowest totals were observed for JJA for all groups.

The highest values of PET were observed for G1 during summer (DJF) and transition to autumn (MA), while G3 presented the highest values in the remaining months. Lowest values of PET were registered for G2 for all months. PET's seasonality is similar to the one observed for air temperature, since this variable is used in its calculation. However, differences are expected since PET is cumulative and air temperature is calculated as a mean. 
446 Overall, all groups presented the highest air temperature values in February 447 (between $22.6 \pm 1.6^{\circ} \mathrm{C}$, for $\mathrm{G} 2$, and $27.5^{\circ} \mathrm{C} \pm 0.6$, for $\mathrm{G} 1$ ). Conversely, the lowest values were observed for July, with a range between $16.2^{\circ} \mathrm{C}( \pm 1.8)$, for $\mathrm{G} 2$, and $21.9^{\circ} \mathrm{C}( \pm$ 0.8), for G1. During the summer months (DJF) and transition to autumn the highest temperatures were observed for G1, while G3 presented the highest temperatures during the remaining months. The lowest air temperatures were observed for G2 during all year, followed by G5. Group G3 was the one with more outliers, while none was present for G5. Finally, the highest and lowest annual amplitudes were registered for G2 and G3, respectively.

Analysis of water deficit and surplus (not shown) revealed that groups G1 and G3 presented the longest periods when P-PET $<0$ (10 and nine months, respectively). For G1, P-PET was positive only for November and December, and for G3 this pattern was observed for NDJ. Those months are classified as the wet season for this region, with the remaining months regarded as the dry season (Frere and Popov 1979). For group G2, the dry season was the shortest among groups, concentrated mostly during autumn (AM) and winter (JJA). For G5, wet season was five-months long (NDJFM), while the dry season occurred from April to October. The raining season tends to be longer and start early (mid-September) in most of the São Paulo state coastal area, while over the Northern Minas Gerais the raining season starts at the end of October (Minuzzi et al. 2007).

\subsubsection{Spatial patterns}

The smallest annual precipitation totals $(<1000 \mathrm{~mm})$ occurred over NE and $\mathrm{N}$ of Minas Gerais state, and NW and N of Rio de Janeiro state (Figure 6). The highest values were observed in NW-SE oriented band over the states of Minas Gerais (center and south), São Paulo (N and NE), and Rio de Janeiro (center and south). This area coincides with the climatological position of the SACZ (Carvalho et al. 2004;

473 Nielsen et al. 2019). Coastal areas of São Paulo and Rio de Janeiro states presented also precipitation totals higher than $1400 \mathrm{~mm}$, most likely associated with FS, and 
475 convective and orographic precipitation (Andrade and Cavalcanti 2018; Brito et al.

476 2017; Seluchi et al. 2011). Precipitation totals over $2000 \mathrm{~mm}$ were also observed in

477 the coastal areas of SEB, likely associated with the combination of synoptic systems

478 (FS and SACZ) with mesoscale systems, in addition to the influence of topography, 479 sea and land breezes and mountain/valley circulations (Brito et al. 2017; Lyra et al. 480 2018).

\section{Figure 6}

482

483

484

485

486

487

488

489

490

491

492

493

494

495

496

497

498

499

500

501

502

503

Altitude, latitude and distance to the coast were determinant in the spatial distribution of mean annual air temperature over SEB (Lima et al. 2010; Sant'Anna Neto 2005). Areas with lowest annual air temperature $\left(<21^{\circ} \mathrm{C}\right)$ were located over complex topography over South Minas Gerais, South and East São Paulo, and Northwest Rio de Janeiro states (Figure 7). This region is approximately parallel to the coast line of states of São Paulo, Rio de Janeiro and Espírito Santo, in addition to coincide with the location of the mountain ranges of Serra da Mantiqueira, Serra do Mar and Caparão. The highest air temperatures $\left(>25^{\circ} \mathrm{C}\right)$ were registered over North Minas Gerais, coastal areas of Espírito Santo, and center and North Rio de Janeiro (coastal plains with altitudes $<50 \mathrm{~m}$ ). Those regions are also characterized by the lowest totals of annual precipitation $(<1000 \mathrm{~mm})$.

\section{Figure 7}

Spatial patterns of PET (Figure 8) were similar to the ones observed for air temperature, with lowest values $(<1200 \mathrm{~mm}$ ) in regions with the highest precipitation and lowest temperature (mountain ranges of Serra da Mantiqueira, Serra do Mar, and border of states of São Paulo, Minas Gerais and Rio de Janeiro). Highest values (>1500 mm) were observed for coastal areas of Rio de Janeiro and Espírito Santo states, North of Minas Gerais and West of São Paulo state (> 1400 $\mathrm{mm}$ ). Those areas are characterized by highlands and lowlands with altitudes lower than $500 \mathrm{~m}$. PET presented a positive gradient towards the coast and negative towards areas of complex topography.

\section{Figure 8}


506 No areas susceptible to desertification over SEB were identified when using index $507 D$, either using observations or gridded data (Figure 9). However, values of $D>1$ were found for some areas, characterizing sub-humid climate. For observations, all stations of group G3, 85\% in group G1 and 69\% in group G4 were also classified as sub-humid climate. Those stations were located mostly over Northeast and North Minas Gerais, and over coastal plains of states of Rio de Janeiro and Espírito Santo. For group G1, only station Presidente Prudente (ID 63, D = 0.99), São Paulo state, was not classified as sub-humid. Stations of groups G2 and G5 were classified as humid, with the exception of station Carbonita (ID 21), in Minas Gerais. Stations in group G2 presented valued of D $<0.70$ for most of its stations ( $79 \%$ of total).

\section{Figure 9}

517 Values for index $D$ based on gridded data indicated similar regions of sub-humid climate found using observed data. This result was likely influenced by the low precipitation totals, high air temperature and high PET over those regions. Those regions are likely to be susceptible to desertification under climate change scenarios for SEB, especially considering increasing air temperature and reduction of precipitation (da Rocha et al. 2014; Marengo et al. 2012; Quintão et al. 2017; Sobral et al. 2020).

Based on observed data, areas of dry sub-humid climate, thus susceptible to desertification, were found for stations of group G3 (except Januária, ID 8) and station Campos dos Goytacazes (G1, ID 53). Those stations were located over North Rio de Janeiro and North Minas Gerais, in areas previously identified as susceptible to desertification (Almeida et al. 2014). Stations already identified as sub-humid by index $D$ were similarly classified by index $I_{a}$.

Areas susceptible to desertification calculated using gridded data were also found over North Minas Gerais and North Rio de Janeiro. However, the area over North Minas Gerais was smaller than the coverage of group G3. This result was likely associated with the underestimation of gridded precipitation, especially for low values, causing overestimation of $I_{a}$. Areas identified by $I_{a}$ (gridded) were also 
535 identified by index $D$ (gridded). Regions identified as susceptible to desertification 536 over states of Rio de Janeiro and Minas Gerais coincide with areas already identified 537 in those states in previous studies (Almeida et al. 2014; Bohn 2014; Marques et al. 538 2017).

\subsection{Policy responses}

In 2015, Brazil instituted the National Policy to Combat Desertification and Mitigate the Effects of Drought (Law number 13153/2015). The objective of this policy is to promote actions for the use of natural resources and sustainable productive initiatives in areas susceptible to desertification (arid, semi-arid and dry sub-humid - defined by an Atlas), as well as the use of protection mechanisms, preservation, conservation and recovery of natural resources.

This study identifies areas susceptible to desertification over the Northern regions of Minas Gerais and Rio de Janeiro states. However, according to the Atlas of Areas Susceptible to Desertification in Brazil (MMA 2007), while Minas Gerais and Espírito Santo are included in the Atlas, Rio de Janeiro is not. Such absence may hamper the implementation of federal measures and actions to combat desertification in this region.

A recent study identified areas highly Susceptible to desertification in the state of Rio de Janeiro (Bohn 2014) and emphasized the need for specific public policies for the region. However, Brazilian government responses have usually been reactive other than proactive, that is, measures are only decided once a new drought begins (Magalhaes 2017). Additionally, Thomas (1997) has long highlighted the importance of scientific research (through innovative tools and processes) in identifying the extent and severity of desertification, as well as suggesting the best possible options to cope with the problem. For that reason, the application of the indices $I_{a}$ and D is a particularly useful tool to support updating the Brazilian Atlas 
565

566

567

568

569

570

571

572

573

574

575

576

577

578

579

580

581

582

583

584

585

586

587

588

and to contribute to strengthen the capacity of the stakeholders and local governments to detect and reduce their vulnerability.

\section{Conclusions}

Time series of precipitation, air temperature and evapotranspiration, as well as aridity indices calculated from GPCC and GHCN gridded data, represent satisfactorily the seasonal and spatial patterns of climate over SEB. Thus, the methodology applied in the current study can be adapted to other regions with similar characteristics, as an instrument of public policies via monitoring of desertification with accessible and reliable data.

The results revealed a horizontal gradient from Central SEB (wet and low temperatures), with humid to sub-humid climate, to its borders, characterized by sub-humid to dry sub-humid climate. An exception to this pattern was South São Paulo state, where climate factors (topography, distance to the coast) and synoptic and mesoscale systems influence the wet climate over the region.

According to index $I_{a}$, Regions North Minas Gerais and North Rio de Janeiro are susceptible to desertification and thus required urgent action of public policies to revert the current status and mitigate future impacts. Index D was not sensitive to classify areas susceptible to desertification based on observed and gridded data.

Similarly, as index $I_{a}$, index D enabled the characterization of several areas with subhumid climate, namely: North and Northeast Minas Gerais state, Espírito Santo (except its Southern part), North Rio de Janeiro and West São Paulo. Based on scenarios of climate change, those regions might be susceptible to desertification in the future, requiring actions in all levels of government to mitigate the factors responsible to this dire phenomenon. 


\section{Acknowledgments}

590 The authors are grateful to the Brazilian National Institute of Meteorology (INMET)

591 for the climatic data and to Fundação Carlos Chagas de Amparo à Pesquisa do Estado 592 do Rio de Janeiro (FAPERJ, call “Apoio a Grupos Emergentes 2013”, process 593 141.663), and Conselho Nacional de Desenvolvimento Científico e Tecnológico 594 (CNPq, call “Universal”, process 483643/2011-4), for the financial support. Gustavo 595 Bastos Lyra is grateful to CNPq for the Productivity Grant in Research process 596 number 435238/2018-3 and Foundation for Research Support of the State of Rio de 597 Janeiro - FAPERJ for the Young Scientist Grant process number E-26/201.501/2014. 598 José Francisco de Oliveira-Júnior is grateful to CNPq for the Productivity Grant in 599 Research process number 309681/2019-7. Gisleine Cunha-Zeri is grateful to 600 Coordination for the Improvement of Higher Education Personnel (CAPES), grant 601 number 88887.308408/2018-00.

602

603 
604

605

606

607

608

609

610

611

612

613

614

615

616

617

618

619

620

621

622

623

624

625

626

627

628

629

\section{Figure captions}

Figure 1 - Map of study area with locations of weather stations, grid points and altitude ( $\mathrm{m}$ above sea level).

Figure 2 - Simple linear regression between observed and gridded precipitation (a), air temperature (b), annual evapotranspiration (c), and aridity indices $I_{a}(\mathrm{~d})$ and D (e).

Figure 3 - Dendrogram of observed data.

Figure 4 - Spatial distribution of five homogeneous groups of climate over Southeast Brazil.

Figure 5 - Boxplots of precipitation (top, $\mathrm{mm}$ ), evapotranspiration (middle, $\mathrm{mm}$ ) and monthly air temperature (bottom, ${ }^{\circ} \mathrm{C}$ ) for groups 1-5. Median indicated by horizontal lines inside boxes and outliers denotes by the black circles.

Figure 6 - Spatial distribution of annual accumulated precipitation (mm) over Southeast Brazil.

Figure 7 - Spatial distribution of mean annual air temperature $\left({ }^{\circ} \mathrm{C}\right)$ over Southeast Brazil.

Figure 8 - Spatial distribution of annual evapotranspiration (mm) over Southeast Brazil.

Figure 9 - Spatial distribution of aridity index D over Southeast Brazil.

Figure 10 - Spatial distribution of aridity index $I_{a}$ over Southeast Brazil.

Figure S1 - Coefficient of determination $\left(\mathrm{r}^{2}\right)$ for precipitation.

Figure S2 - Willmott's index of agreement (d) for precipitation.

Figure S3 - Root Mean Squared Error (RMSE, \%) of gridded precipitation from the Global Precipitation Climatology Center (GPCC) in relation to observed data.

Figure S4 - Coefficient of determination $\left(\mathrm{r}^{2}\right)$ for air temperature.

Figure S5 - Willmott's index of agreement (d) for air temperature. 
630 Figure S6 - Root Mean Squared Error (RMSE, \%) of gridded air temperature from 631 the Global Historical Climatology (GHCN) in relation to observations.

632 Figure S7 - Coefficient of determination $\left(r^{2}\right)$ for evapotranspiration.

633 Figure S8 - Willmott's index of agreement of evapotranspiration.

634 Figure S9 - Root Mean Squared Error (RMSE, \%) of evapotranspiration from gridded 635 data (GPCC and GHCN) in relation to observations.

636 


\section{Table captions}

638 Table 1 - Identification (ID), location (coordinates, altitude) and homogeneous 639 groups of weather stations.

640 Table 2 - Classification drought according to aridity index $I_{a}$.

641 Table 3 - Statistical analyses of observed data in relation to gridded data.

642 


\section{References}

Almeida JB, Moreira AA, Fernandes FHS et al (2014) O sensoriamento remoto aplicado ao estudo da desertificação na região semiárida do norte de Minas Gerais. Rev Bras Geomática. https://doi.org/10.3895/rbgeo.v2n2.5450

Alvares CA, Stape JL, Sentelhas PCC et al (2013) Köppen's climate classification map for Brazil. Meteorol Zeitschrift. https://doi.org/10.1127/0941-2948/2013/0507

Alves RBO, Silva HP, Araújo Filho JC et al (2020) Use of Vegetation Cover Index (ICV) to Identify Susceptible Areas to Desertification Process in the Municipalities of Betânia, Floresta and Itacuruba, Pernambuco, Brazil. J Hyperspectral Remote Sens. https://doi.org/10.29150/jhrs.v9.6.p343-352

Ambrizzi T, Ferraz SET (2015) An objective criterion for determining the South Atlantic Convergence Zone. Front Environ Sci. https://doi.org/10.3389/fenvs.2015.00023

Andrade KM, Cavalcanti IFA (2018) Atmospheric characteristics that induce extreme precipitation in frontal systems over Southeastern Brazil during summer: Observations and atmospheric model simulation. Int J Climatol. https://doi.org/10.1002/joc.5744

Bohn L (2014) Susceptibilidade à desertificação no estado do Rio de Janeiro : práticas agroecológicas como alternativa de mitigação. Universidade Federal Rural do Rio de Janeiro

Brasiliense CS, Dereczynski CP, Satyamurty P et al (2018) Synoptic analysis of an intense rainfall event in Paraíba do Sul river basin in southeast Brazil. Meteorol Appl. https://doi.org/10.1002/met.1670

Brito TT, Oliveira-Júnior JF, Lyra GB et al (2017) Multivariate analysis applied to monthly rainfall over Rio de Janeiro state, Brazil. Meteorol Atmos Phys. https://doi.org/10.1007/s00703-016-0481-x

Carvalho LMV, Jones C, Liebmann B (2004) The South Atlantic Convergence Zone: Intensity, Form, Persistence, and Relationships with Intraseasonal to Interannual Activity and Extreme Rainfall. J Clim. https://doi.org/10.1175/15200442(2004)017<0088:TSACZI>2.0.CO;2

Cataldi M, Assad LPDF, Torres-Júnior AR, Alves JLD (2010) Estudo da influência das anomalias da TSM do Atlântico Sul extratropical na região da Confluência BrasilMalvinas no regime hidrometeorológico de verão do Sul e Sudeste do Brasil. Rev Bras Meteorol. https://doi.org/10.1590/S0102-77862010000400010

Coelho CAS, Oliveira CP, Ambrizzi T et al (2016) The 2014 southeast Brazil austral summer drought: regional scale mechanisms and teleconnections. Clim Dyn 46:3737-53

Cunningham C (2020) Characterization of dry spells in Southeastern Brazil during the monsoon season. Int J Climatol. https://doi.org/joc.6478. doi: 10.1002/joc.6478

Donat MG, Sillmann J, Wild S et al (2014) Consistency of Temperature and Precipitation Extremes across Various Global Gridded In Situ and Reanalysis Datasets. J Clim. https://doi.org/10.1175/JCLI-D-13-00405.1 
Ferreira TR, Di Pace FT, Silva BB, Delgado JR (2017) Identification of desertification sensitive areas in the brazilian northeast through vegetation indices. Eng Agrícola. https://doi.org/10.1590/1809-4430-eng.agric.v37n6p1190-1202/2017

Frere M, Popov GF (1979) Agrometeorological crop monitoring and forecasting. Roma

Gois G, Oliveira-Júnior JF, Silva-Júnior CA et al (2020) Statistical normality and homogeneity of a 71-year rainfall dataset for the state of Rio de Janeiro-Brazil. Theor Appl Climatol. https://doi.org/10.1007/s00704-020-03270-9

Hare FK (1983) Climate and Desertification: a revised analysis. Geneva

Jones PD, Moberg A (2003) Hemispheric and large-scale surface air temperature variations: An extensive revision and an update to 2001. J Clim. https://doi.org/10.1175/1520-0442(2003)016<0206:HALSSA>2.0.CO;2

Kalnay E, Kanamitsu M, Kistler R et al (1996) The NCEP NCAR 40-Year Reanalysis Project. Bull Am Meteorol Soc 77:437-472

Kanamitsu M, Ebisuzaki W, Woollen J et al (2002) NCEP-DOE AMIP-II Renalalysys (R-2). Bull Am Meteorol Soc. https://doi.org/10.1175/BAMS-83-11

Kawanishi T, Kuroiwa H, Kojima M et al (2000) TRMM Precipitation Radar. Adv Sp Res. https://doi.org/10.1016/S0273-1177(99)00932-1

Kawanishi T, Takamatsu H, Kozu T et al (1993) TRMM precipitation radar. In: Better Understanding of Earth Environment, International. IEEE. pp 423-425

Kelly P, Mapes B (2016) February Drying in Southeastern Brazil and the Australian Monsoon: Global Mechanism for a Regional Rainfall Feature. J Clim. https://doi.org/10.1175/JCLI-D-15-0838.1

Lima KC, Satyamurty P, Fernandez JPR (2010) Large-scale atmospheric conditions associated with heavy rainfall episodes in southeast Brasil. Theor Appl Climatol 101:121-135

Lyra GB, Correia TP, Oliveira-Júnior JF, Zeri M (2018) Evaluation of methods of spatial interpolation for monthly rainfall data over the state of Rio de Janeiro, Brazil. Theor Appl Climatol. https://doi.org/10.1007/s00704-017-2322-3

Loyola HBM, Cutter SL, Emrich CT (2016) Social Vulnerability to Natural Hazards in Brazil. Int J Disaster Risk Sci. https://doi.org/10.1007/s13753-016-0090-9

Macharia JM, Ngetich FK, Shisanya CA (2020) Comparison of satellite remote sensing derived precipitation estimates and observed data in Kenya. Agric For Meteorol. https://doi.org/10.1016/j.agrformet.2019.107875

Magalhaes AR (2017) Life and drought in Brazil. In: Nys E de, Eagle NL, Magalhaes AR (eds) Drought in Brazil: proactive management and policy, 1st Editio. Taylor \& Francis Group, Boca Raton, FL, pp 1-18

Marengo JA, Alves LM, Alvala RCS et al (2017) Climatic characteristics of the 20102016 drought in the semiarid Northeast Brazil region. An Acad Bras Cienc. https://doi.org/10.1590/0001-3765201720170206.

Marengo JA, Chou SC, Kay G et al (2012) Development of regional future climate change scenarios in South America using the Eta CPTEC/HadCM3 climate change 
projections: climatology and regional analyses for the Amazon, São Francisco and the Paraná River basins. Clim Dyn. https://doi.org/10.1007/s00382-011-1155-5

Marques MVA, Moreira AA, Nery CVM (2017) Diagnóstico da desertificação na região norte de Minas Gerais por meio de técnicas de geoprocessamento. Bol Geogr. https://doi.org/10.4025/bolgeogr.v35i2.27361

Minuzzi RB, Sediyama GC, Barbosa EM, Melo-Júnior JCF (2007) Climatologia do comportamento do período chuvoso da região sudeste do Brasil. Rev Bras Meteorol. https://doi.org/10.1590/S0102-77862007000300007

Mirzabaev A, Wu J, Evans J et al (2019) Climate change and land. Chapter 3: Desertification. IPCC Spec Rep Glob Warm $15^{\circ} \mathrm{C} 174$

MMA (2007) Atlas das Areas Susceptiveis a Desertificação do Brasil. 136

Monteiro JAF, Strauch M, Srinivasan R et al (2016) Accuracy of grid precipitation data for Brazil: application in river discharge modelling of the Tocantins catchment. Hydrol Process. https://doi.org/10.1002/hyp.10708

Mourtzinis S, Rattalino EJI, Conley SP, Grassini P (2017) From grid to field: Assessing quality of gridded weather data for agricultural applications. Eur J Agron. https://doi.org/10.1016/j.eja.2016.10.013

Murtagh F (1985) Multidimensional Clustering Algorithms. Physica-Verlag, Wuerzburg

Nielsen DM, Belém AL, Marton E, Cataldi M (2019) Dynamics-based regression models for the South Atlantic Convergence Zone. https://doi.org/10.1007/s00382018-4460-4

Nimer E (1972) Climatologia da Região Sudeste do Brasil - Introdução a Climatologia Dinâmica. Rev Bras Geogr 34:3-48

NOAA (2020) National Oceanic and Atmospheric Administration

Nobre P, Siqueira LSP, De Almeida RAF et al (2013) Climate simulation and change in the brazilian climate model. J Clim. https://doi.org/10.1175/JCLI-D-12-00580.1

Oliveira-Júnior JF, Lyra GB, Góis G et al (2012) Análise de homogeneidade de séries pluviométricas para determinação do índice de seca IPP no Estado de Alagoas. Floresta e Ambient. https://doi.org/10.4322/floram.2012.011

Penman HL (1953) The physical bases of irrigation control. Hort Congr 2 913-924

Peterson TC, Vose RS (1997) An overview of the global historical climatology network-daily database. Bull Am Meteorol Soc. https://doi.org/10.1175/JTECH-D11-00103.1

Quintão AF, Brito I, Oliveira F et al (2017) Social, Environmental, and Health Vulnerability to Climate Change: The Case of the Municipalities of Minas Gerais, Brazil. J Environ Public Health. https://doi.org/10.1155/2017/2821343

R Development Core Team (2011) R: A language and environment for statistical computing. R Foundation for Statistical Computing, Vienna, Austria

Rao VB, Franchito SH, Santo CME, Gan MA (2016) An update on the rainfall characteristics of Brazil: seasonal variations and trends in 1979-2011. Int J 
Reynolds JF, Smith DMS, Lambin EF et al (2007) Global Desertification: Building a Science for Dryland Development. Science. https://doi.org/10.1126/science.1131634

Rocha RP, Reboita MS, Dutra LMM et al (2014) Interannual variability associated with ENSO: present and future climate projections of RegCM4 for South AmericaCORDEX domain. Clim Change. https://doi.org/10.1007/s10584-014-1119-y

Rodrigues RR, Taschetto AS, Gupta AS, Foltz GR (2019) Common cause for severe droughts in South America and marine heatwaves in the South Atlantic. Nat Geosci 12:620-626

Sant'Anna Neto JL (2005) Decálogo da Climalotogia do Sudeste Brasileiro. Rev Bras Climatol 1:43-60

Santos JC, Prado DO, Lyra GB, Santos EO (2018) Séries climáticas em grade de precipitação e temperatura do ar em região de relevo complexo. Rev Bras Climatol. https://doi.org/10.5380/abclima.v23i0.54263

Satyamurty P, Nobre CA, Silva Dias PL (1998) South America. In: Meteorology of the Southern Hemisphere, American Meteorological Society, 27th edn. Boston, MA, pp 119-139

Schneider U, Becker A, Finger P et al (2014) GPCC's new land surface precipitation climatology based on quality-controlled in situ data and its role in quantifying the global water cycle. Theor Appl Climatol. https://doi.org/10.1007/s00704-0130860-x

Seluchi ME, Chan Chou S, Gramani M (2011) A case study of a winter heavy rainfall event over the Serra do Mar in Brazil. Geofísica Int 50:41-56

Silva KR, Cecílio RA, Xavier AC et al (2011) Interpolação Espacial da Precipitação no Estado do Espírito Santo. Floresta e Ambient. https://doi.org/10.4322/floram.2011.061

Sivakumar B, Jayawardena AW, Li WK (2007) Hydrologic complexity and classification: a simple data reconstruction approach. Hydrol Process. https://doi.org/10.1002/hyp.6362

Sivakumar MVK (2007) Interactions between climate and desertification. Agric For Meteorol. https://doi.org/10.1016/j.agrformet.2006.03.025

Sobral BS, Oliveira-Júnior JF, Alecrim F et al (2020) PERSIANN-CDR based characterization and trend analysis of annual rainfall in Rio De Janeiro State, Brazil. Atmos Res. https://doi.org/10.1016/j.atmosres.2020.104873

Sobral BS, Oliveira-Júnior JF, Gois G et al (2018) Variabilidade espaço-temporal e interanual da chuva no estado do Rio de Janeiro. Rev Bras Climatol. https://doi.org/10.5380/abclima.v22i0.55592

Thomas DSG (1997) Science and the desertification debate. J Arid Environ. https://doi.org/10.1006/jare.1997.0293

Thornthwaite CW (1948) An approach toward a rational classification of climate. Geogr Rev 38:55-94 
Thornthwaite CW, Mather JR (1955) The Water Balance. Publ Climatol 104

Tomasella J, Silva Pinto Vieira RM, Barbosa AA et al (2018) Desertification trends in the Northeast of Brazil over the period 2000-2016. Int J Appl Earth Obs Geoinf. https://doi.org/10.1016/j.jag.2018.06.012

Tostes JO, Lyra GB, Oliveira- Júnior JF, Francelino MR (2017) Assessment of gridded precipitation and air temperature products for the State of Acre, southwestern Amazonia, Brazil. Environ Earth Sci. https://doi.org/10.1007/s12665-017-6467-2

Vicente-Serrano SM, Saz-Sánchez MA, Cuadrat JM (2003) Comparative analysis of interpolation methods in the middle Ebro Valley (Spain): application to annual precipitation and temperature. Clim Res. https://doi.org/10.3354/cr024161

Vieira RMSP, Sestini MF, Tomasella J et al (2020) Characterizing spatio-temporal patterns of social vulnerability to droughts, degradation and desertification in the Brazilian northeast. Environ Sustain Indic. https://doi.org/10.1016/j.indic.2019.100016

Vieira RMSP, Tomasella J, Alvalá RCS et al (2015) Identifying areas susceptible to desertification in the Brazilian northeast. Solid Earth. https://doi.org/10.5194/se-6347-2015

Ward JH (1963) Hierarchical Grouping to Optimize an Objective Function. J Am Stat Assoc. https://doi.org/10.1080/01621459.1963.10500845

Wilks DS (1995) Statistical Methods In The Atmospheric Sciences: An Introduction. Academic Press, San Diego

Willmott CJ (1981) On the validation of models. Phys Geogr 2:184-194

Willmott CJ, Matsuura K, Legates DR (2001) Terrestrial air temperature and precipitation: monthly and annual time series (1950-1999). Cent Clim Res version 1: 


\section{Figures}
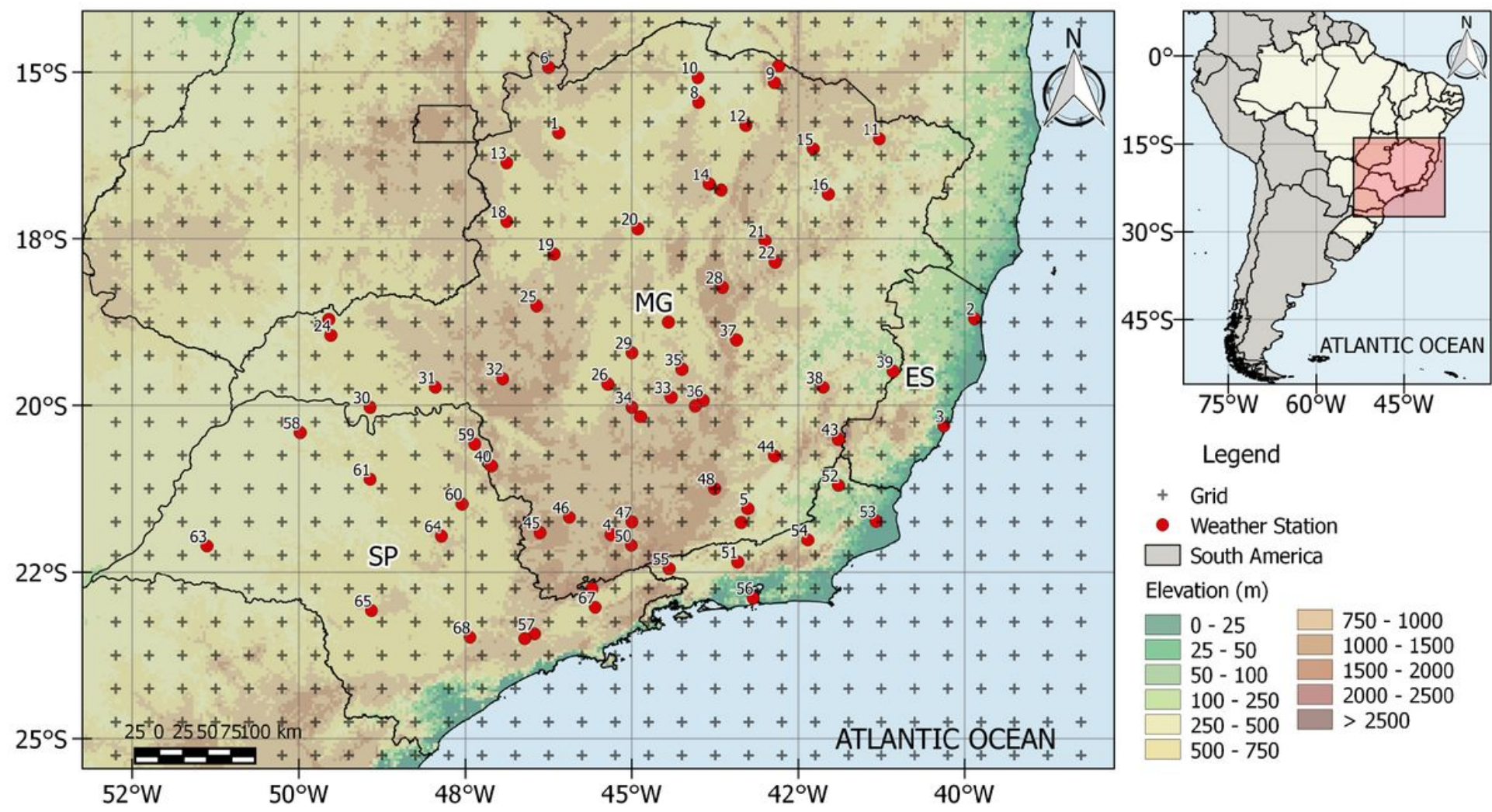

Legend

+ Grid

- Weather Station South America

Elevation (m)

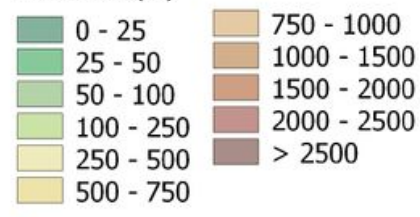

\section{Figure 1}

Map of study area with locations of weather stations, grid points and altitude ( $\mathrm{m}$ above sea level). Note: The designations employed and the presentation of the material on this map do not imply the expression of any opinion whatsoever on the part of Research Square concerning the legal status of any country, territory, city or area or of its authorities, or concerning the delimitation of its frontiers or boundaries. This map has been provided by the authors. 


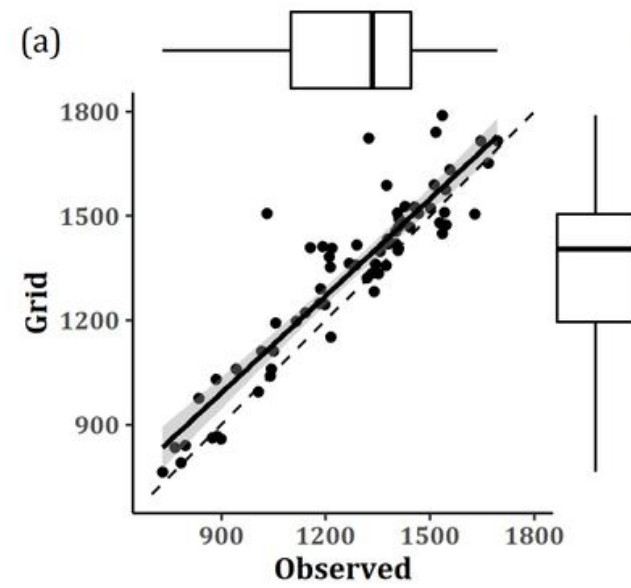

(b)

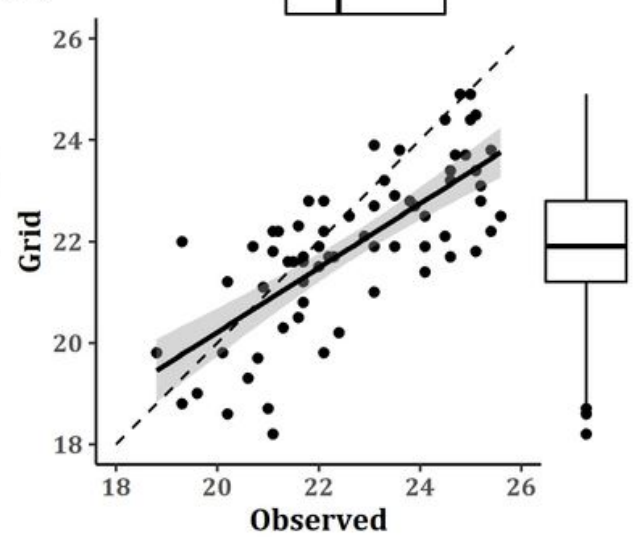

(d)

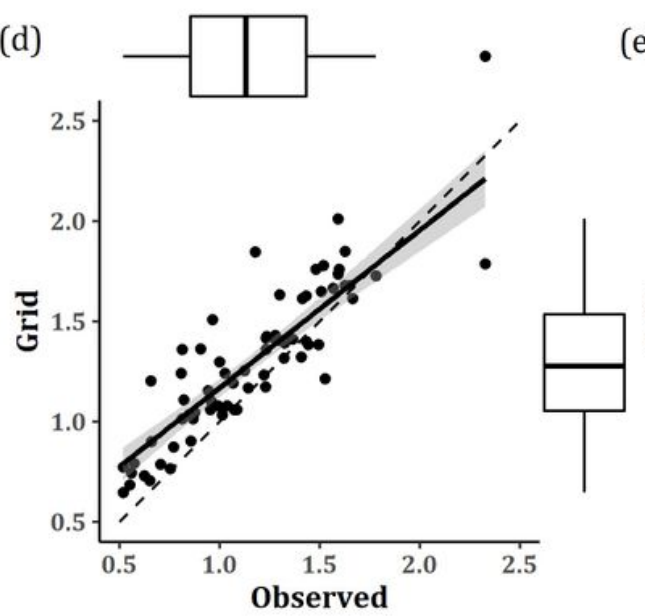

(e)

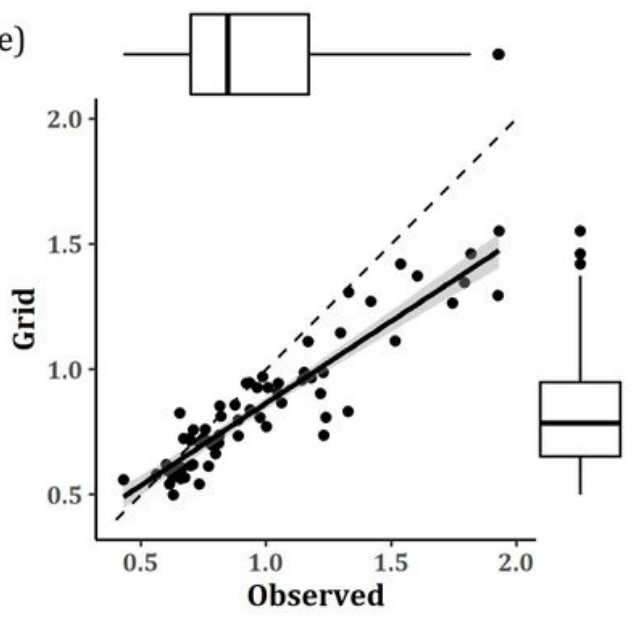

(c)

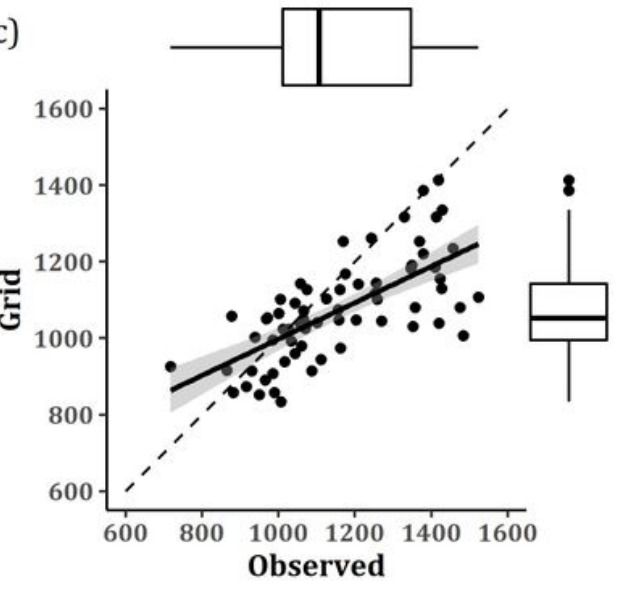

\section{Figure 2}

Simple linear regression between observed and gridded precipitation (a), air temperature (b), annual evapotranspiration (c), and aridity indices la (d) and D (e). 


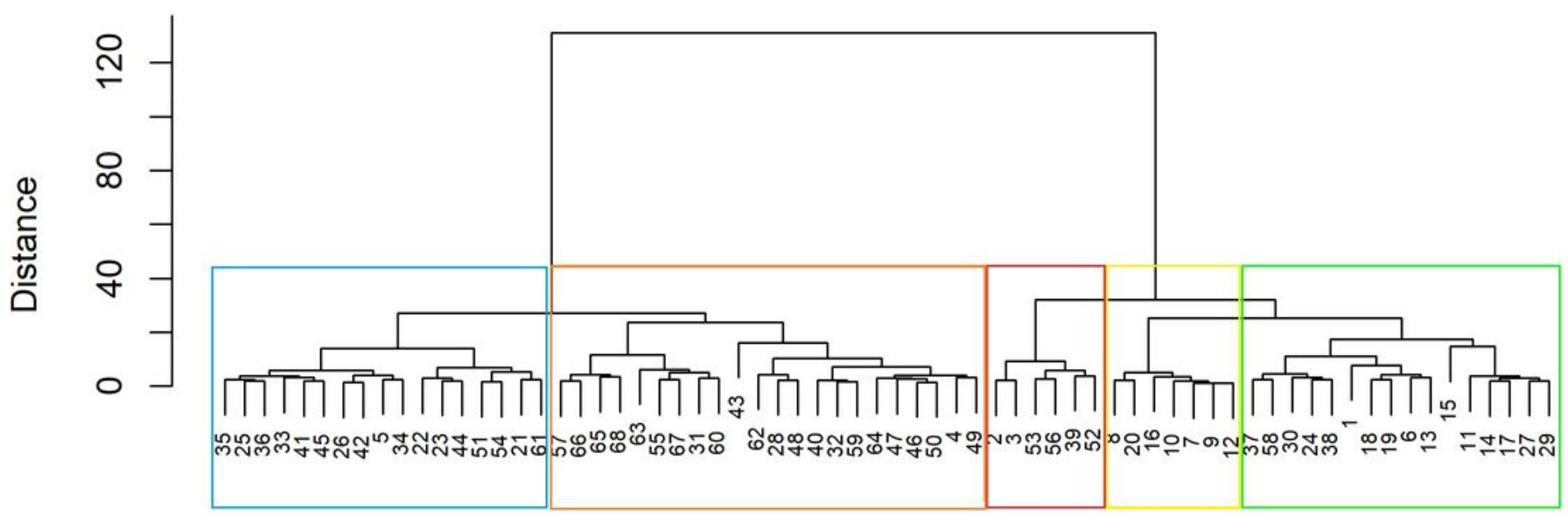

Figure 3

Dendrogram of observed data. 


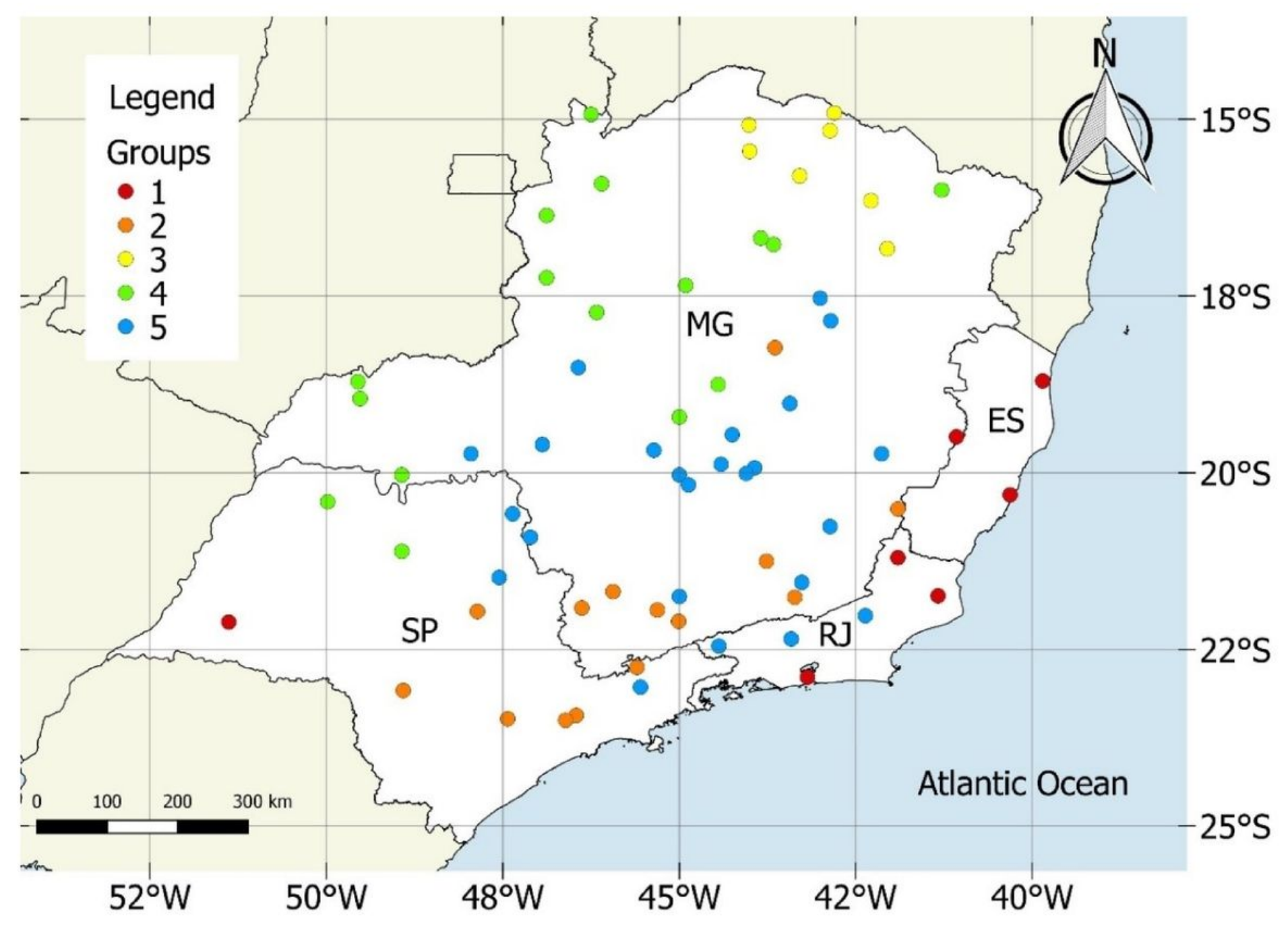

Figure 4

Spatial distribution of five homogeneous groups of climate over Southeast Brazil. Note: The designations employed and the presentation of the material on this map do not imply the expression of any opinion whatsoever on the part of Research Square concerning the legal status of any country, territory, city or area or of its authorities, or concerning the delimitation of its frontiers or boundaries. This map has been provided by the authors. 


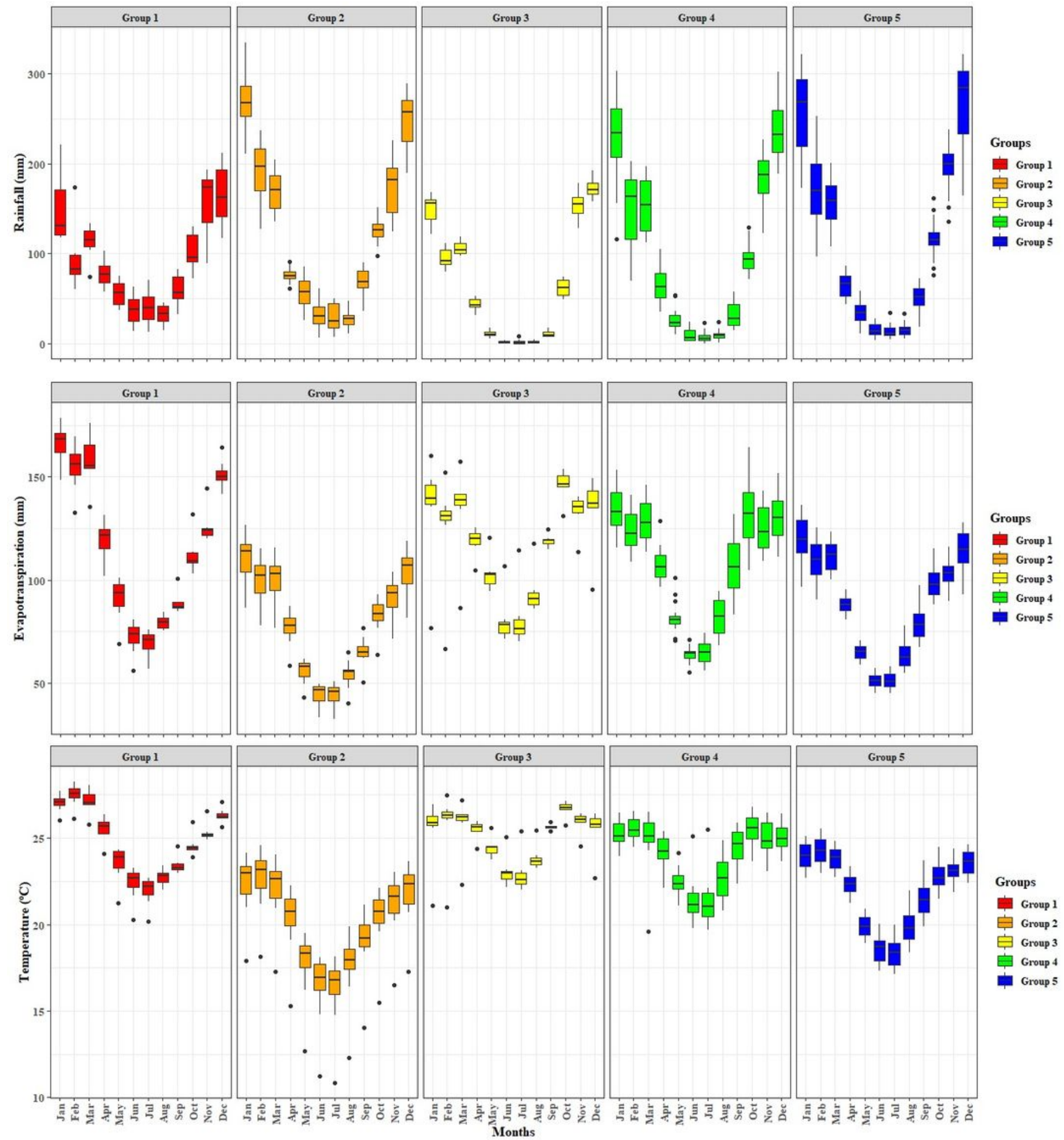

Figure 5

Boxplots of precipitation (top, $\mathrm{mm}$ ), evapotranspiration (middle, $\mathrm{mm}$ ) and monthly air temperature (bottom, ${ }^{\circ} \mathrm{C}$ ) for groups $1-5$. Median indicated by horizontal lines inside boxes and outliers denotes by the black circles. 


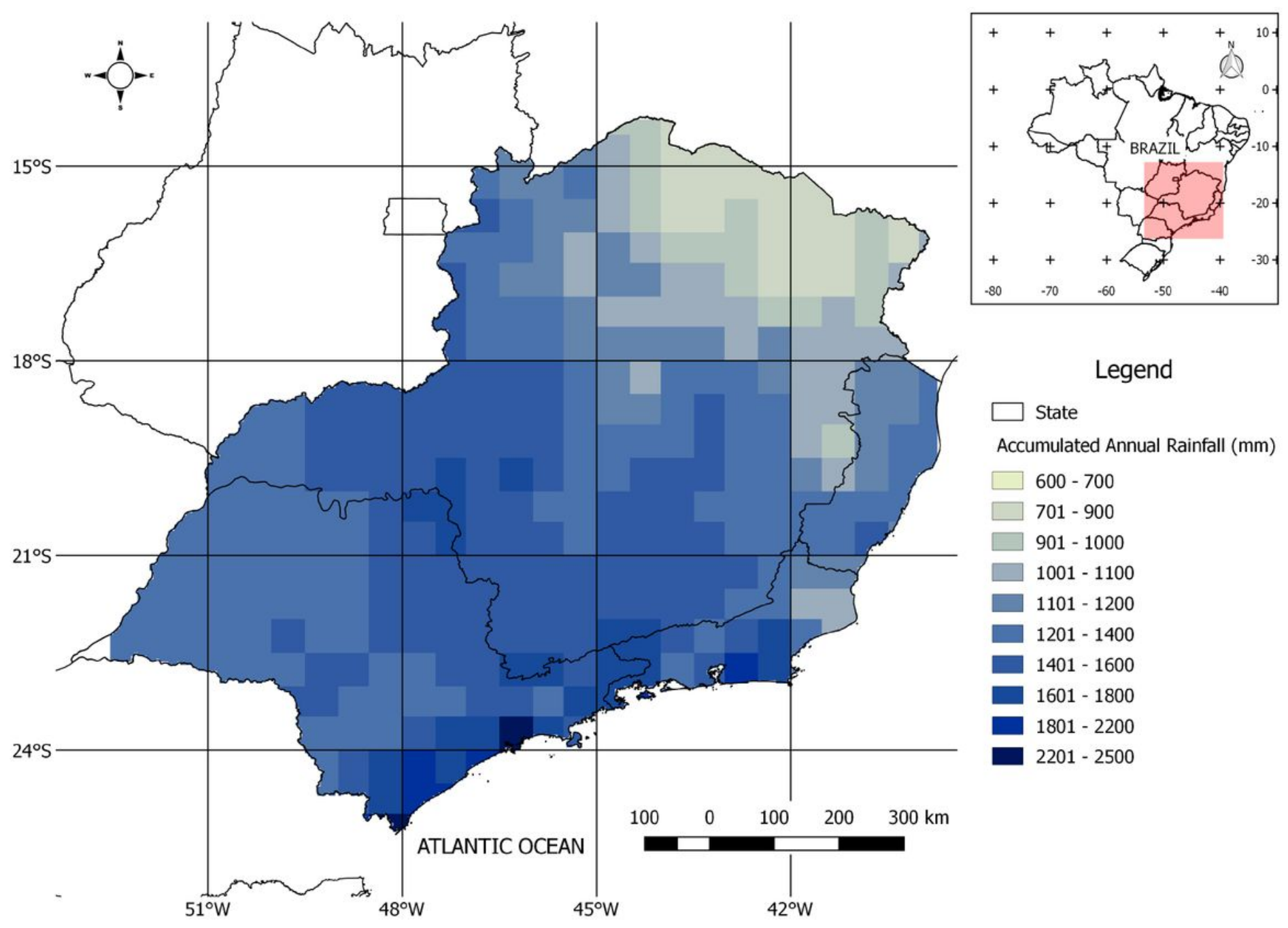

Figure 6

Spatial distribution of annual accumulated precipitation $(\mathrm{mm})$ over Southeast Brazil. Note: The designations employed and the presentation of the material on this map do not imply the expression of any opinion whatsoever on the part of Research Square concerning the legal status of any country, territory, city or area or of its authorities, or concerning the delimitation of its frontiers or boundaries. This map has been provided by the authors. 


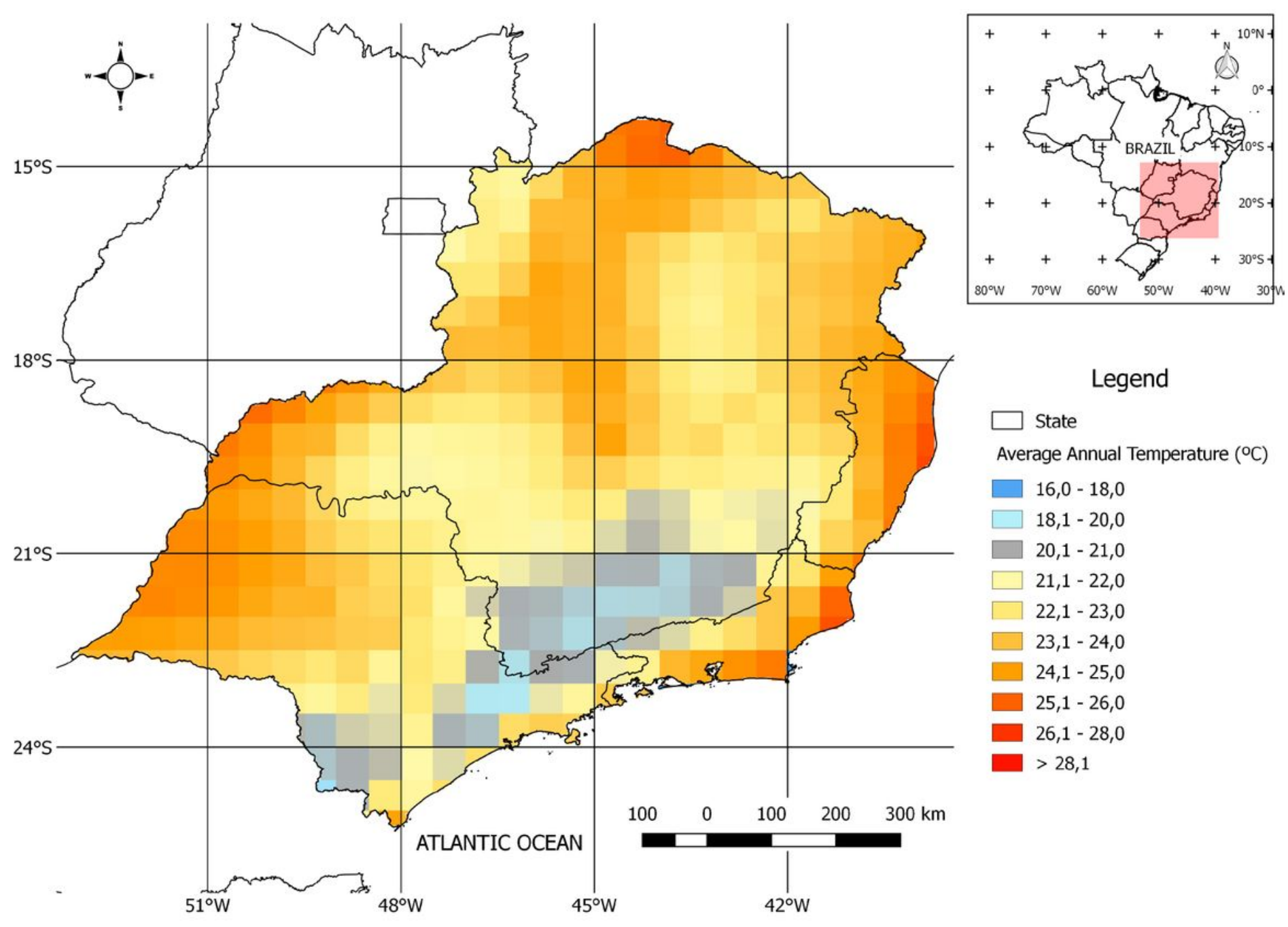

Figure 7

Spatial distribution of mean annual air temperature $\left({ }^{\circ} \mathrm{C}\right)$ over Southeast Brazil. Note: The designations employed and the presentation of the material on this map do not imply the expression of any opinion whatsoever on the part of Research Square concerning the legal status of any country, territory, city or area or of its authorities, or concerning the delimitation of its frontiers or boundaries. This map has been provided by the authors. 


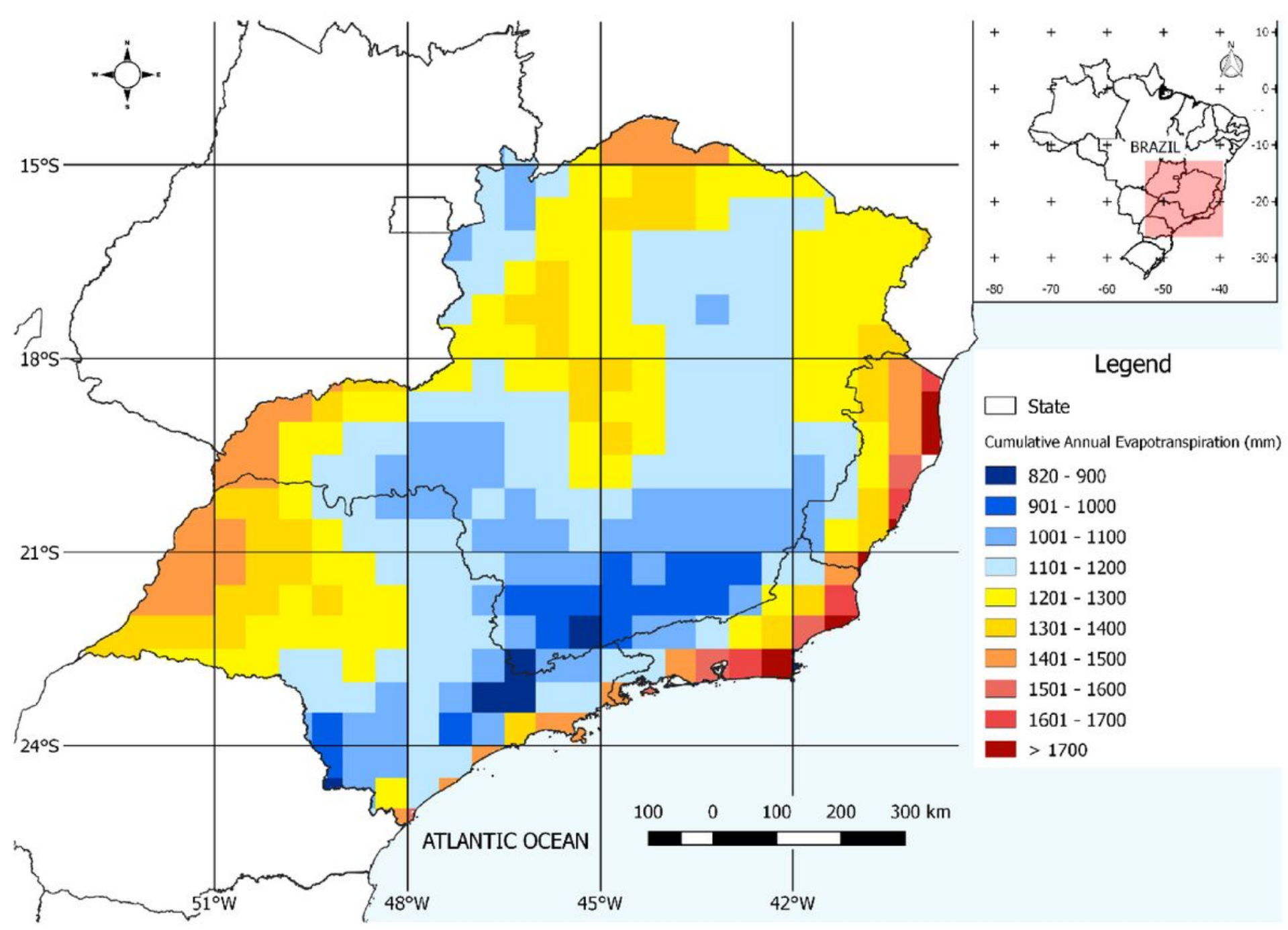

Figure 8

Spatial distribution of annual evapotranspiration $(\mathrm{mm})$ over Southeast Brazil. Note: The designations employed and the presentation of the material on this map do not imply the expression of any opinion whatsoever on the part of Research Square concerning the legal status of any country, territory, city or area or of its authorities, or concerning the delimitation of its frontiers or boundaries. This map has been provided by the authors. 


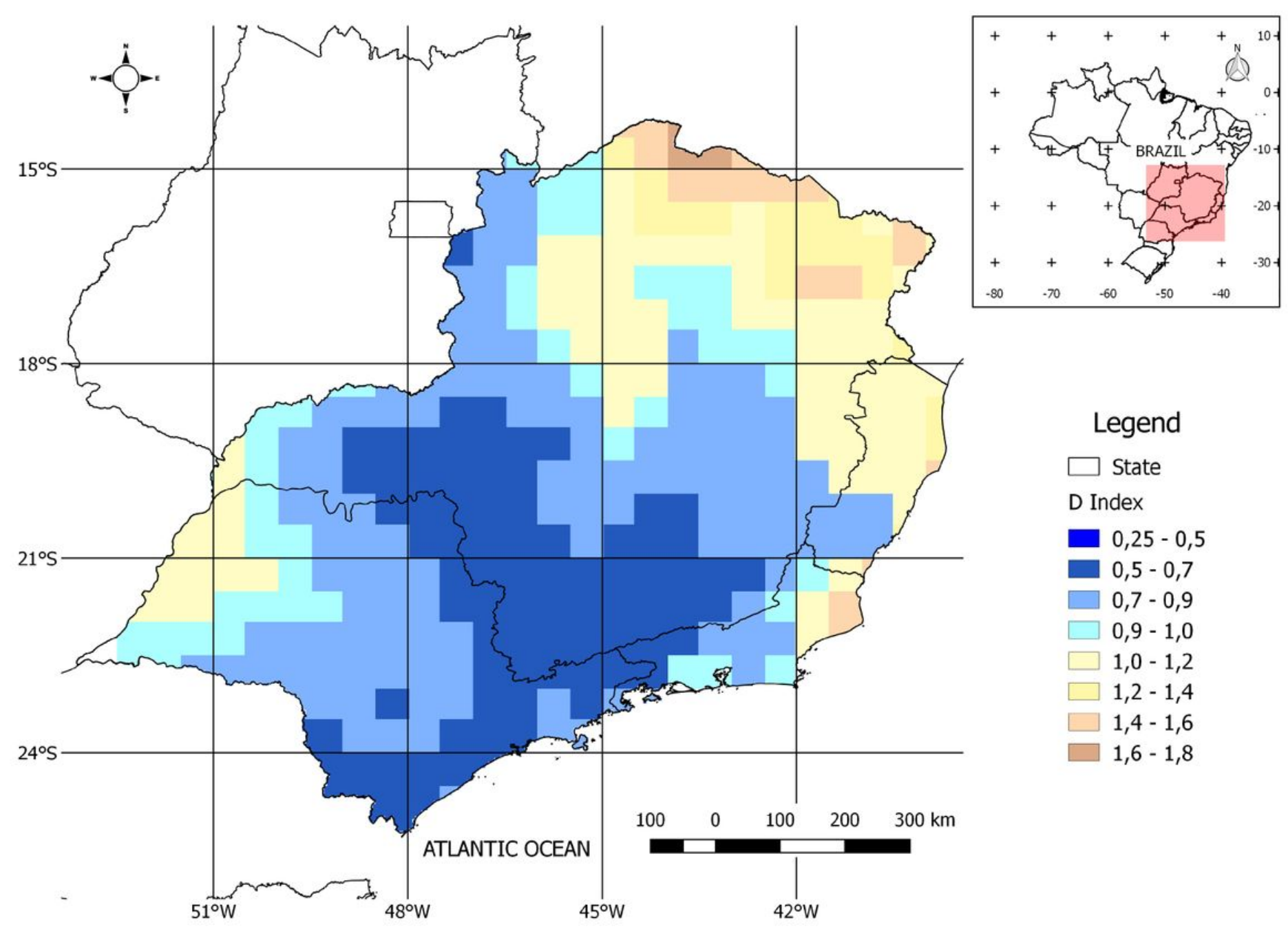

Figure 9

Spatial distribution of aridity index D over Southeast Brazil. Note: The designations employed and the presentation of the material on this map do not imply the expression of any opinion whatsoever on the part of Research Square concerning the legal status of any country, territory, city or area or of its authorities, or concerning the delimitation of its frontiers or boundaries. This map has been provided by the authors. 


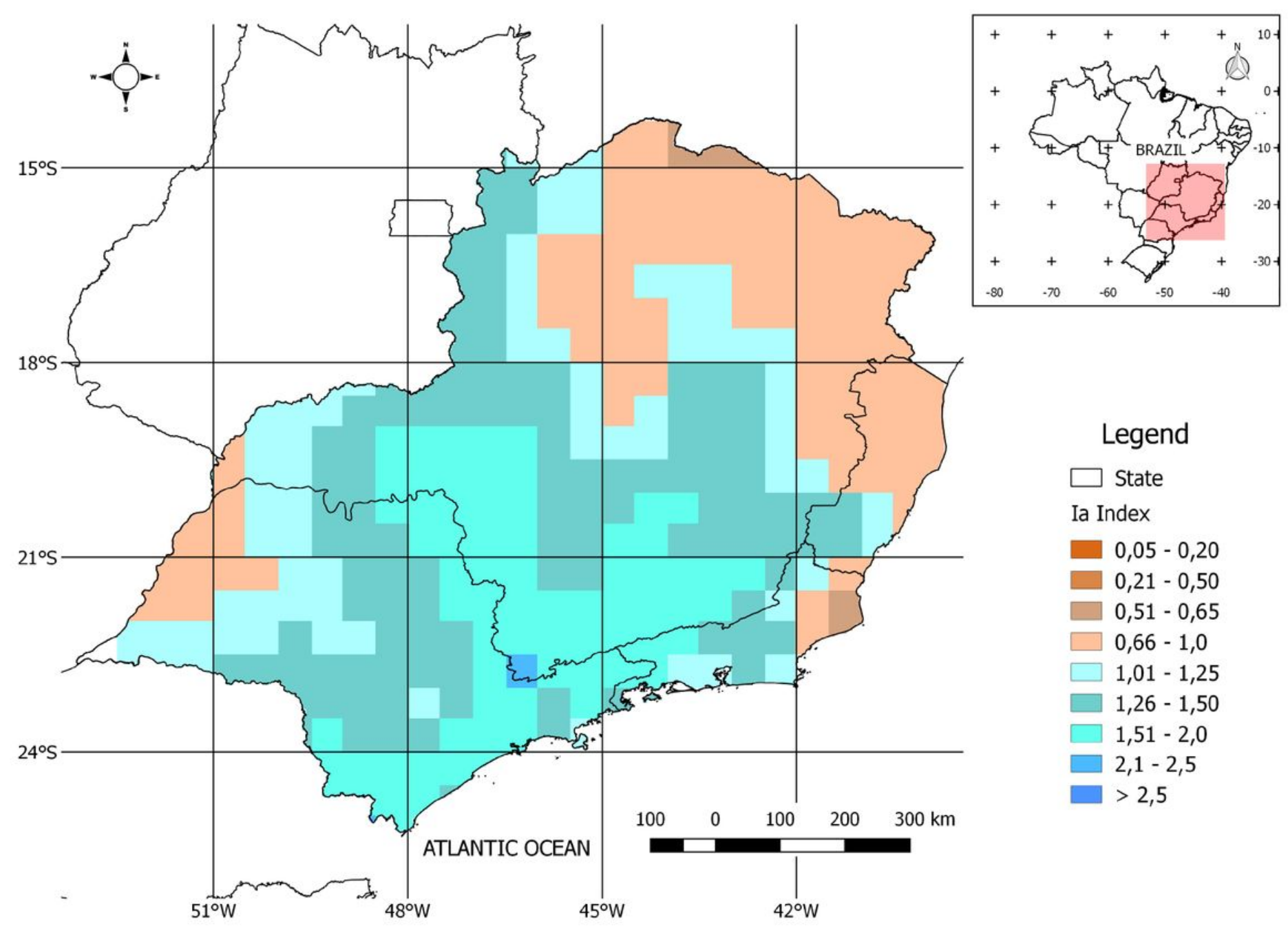

Figure 10

Spatial distribution of aridity index la over Southeast Brazil. Note: The designations employed and the presentation of the material on this map do not imply the expression of any opinion whatsoever on the part of Research Square concerning the legal status of any country, territory, city or area or of its authorities, or concerning the delimitation of its frontiers or boundaries. This map has been provided by the authors.

\section{Supplementary Files}

This is a list of supplementary files associated with this preprint. Click to download.

- S1.tif

- S2.tif

- S3.tif

- S4.tif

- S5.tif 
- S6.tif

- S7.tif

- S8.tif

- S9.tif 